\title{
Financial Literacy and Stokvels Savings of Low-Income Households in South Africa
}

\author{
Submitted 01/10/21, 1st revision 14/10/21, 2nd revision 04/11/21, accepted 30/11/21
}

\section{Lindiwe Ngcobo $^{1}$}

\begin{abstract}
:
Purpose: Despite the fact that low-income households have limited financial literacy and are regarded as unbanked, they still earn higher returns on their savings. The aim of this study was to examine financial literacy and stokvels savings of low-income households in South Africa.

Design/Methodology/Approach: The study is using a quantitative research methodology (descriptive statistics and correlation analysis) with data collected from questionnaires administered to respondents in Gauteng province.

Findings: The results revealed that more females $(52,3 \%)$ than males $(45,1 \%)$ participate in stokvels. As regards the education levels of participants, most respondents indicated that they had a matric (33,9\%) or had no schooling (16,8\%). It was found that low-income households tend to invest in stokvels to provide for high festive season cash requirements (with the highest mean of 4,62) while others invest in pyramid schemes to generates lots of income (with the lowest mean of 4,07).

Practical Implications: These results may be used to guide policymakers in terms of where emphasis should be placed regarding financial literacy in savings for low-income South African households.

Originality value: An examinination was done in financial literacy and stokvels savings of low-income households in South Africa. Furthermore, stokvels are regarded as unbanked. The results revealed that stokvels low-income households are generally financially illiterate contrary to many studies the relationship between stokvels and savings is not assymetry.
\end{abstract}

Keywords: Savings, financial literacy, stokvels.

JEL codes:

Paper type: Research article.

Acknowledgment: This research paper is a product of my unpublished master's degree 2018 thesis entitled: "The nature and characteristics of credit instruments issued by stokvels in South Africa”. This thesis may be found in the UNISA repository but is unpublished material.

\footnotetext{
${ }^{1}$ University of South Africa, Pretoria, South Africa, Email: LNgcobo@unisa.ac.za;
} 


\section{Introduction}

Limited financial literacy and a lack of information affect the ability to save and access to credit by low-income households (Lusardi, 2008). Moreover, the majority of individuals who are financially illiterate are unable to save with financial institutions (Lusardi and Mitchell, 2007). Low-income households will only demand financial services and products if they have enough information about them (Cole et $a l ., 2011$ ). FinMark Trust (2008) further indicates that a lack of financial literacy (as per Figure 1 below) contributes to the low savings culture in South Africa.

Figure 1. Desired financial knowledge (FinMark Trust, 2008)

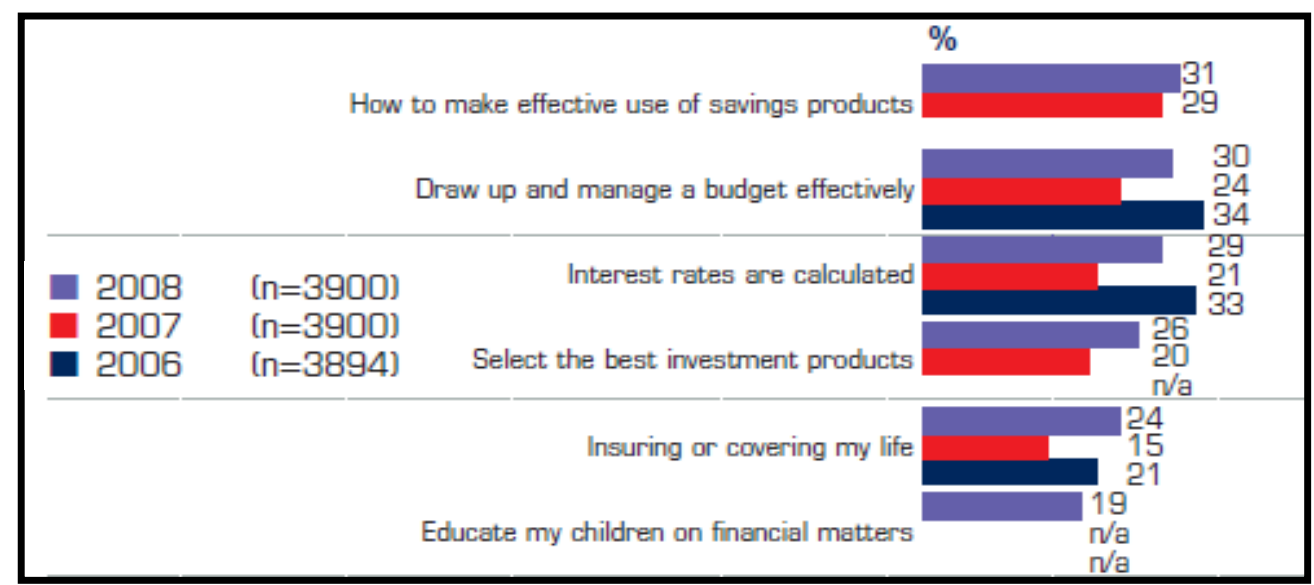

Source: Own study.

It is evident from the preceding exposition that there is a weak culture of saving in South Africa and saving is not being encouraged as rigorously as credit is sought (Engelbrecht, 2009). Change could only be effected through legislation, putting pressure on low-income households to save (Engelbrecht, 2009). According to FinMark Trust (2007), low-income households' willingness to save is positively correlated with education levels and, more specifically, financial literacy, which should be based on general theories of saving behaviour.

However, Jappelli, and Padula (2011) established that limited financial literacy and savings are positively correlated, which explains why in the South African case both savings and financial literacy are low. Lusardi and Mitchell (2007) argued that the lack of financial education and discipline in compiling and reconciling a budget is a problem among low-income households. Financial literacy is particularly important because, with greater knowledge people, are less likely to fall victim to unscrupulous moneylenders who might be offering inappropriate products with no transparency at high interest rates.

Financial literacy is believed to be one of the most important barriers to accessing credit. Stokvels fill the gap by providing education to low-income households with 
savings and the best ways to improve their lives. The objective of this study was specifically to link the presence of financial literacy and stokvel savings in lowincome households. The literature work is guided by the theories, which are summarised by Lusardi (2008) as additional evidence that lack of financial literacy is considered a severe impediment to saving. Consequently, the government together with educators has promoted financial education programmes.

Moreover, Lusardi and Mitchell (2014) shows that few individuals possess the necessary financial skills required to make decisions to save or invest and consume between periods. Gale and Levine (2010) define financial literacy as the ability to make informed judgements and effective decisions regarding the use and management of money and wealth. Baron (2015) describes financial literacy as reading and writing, is most commonly target as an approach to provide spaces for empowerment for marginalised low-income households.

The remainder of this article is structured as follows: section 2 contains a literature review, section 3 describes the methodology used, section 4 discusses and interprets the results, while section 5 summarises the study.

\section{Literature Review}

Finscope research estimates that the membership savings of burial societies and stokvels contribute between R25 billion and R44 billion to the national economy (South African Government, 2015). According to a 2014 report by African Response, based on the latest survey on the status and market potential of stokvels, there are 8,6 million stokvel members in South Africa which represents $23 \%$ of the adult population and an estimated 421000 stokvels in total. On average, stokvel members belong to 1,3 stokvels. The number of individuals belonging to stokvels has increased to an average of 31 members per stokvel. This makes sense when considering that burial societies are now the biggest segment of the stokvel market as they are typically bigger groups. Membership of burial stokvels goes up as high as 100 members per group, while savings, investment and birthday stokvels reflect a much lower membership per stokvel.

However, the South African Savings Institute (2019) has noted that the household saving rate in South Africa increased to $-0.10 \%$ in the first quarter of 2019 , from -0 , $50 \%$ in the fourth quarter of 2018. Personal savings in South Africa averaged $4,75 \%$ from 1960 up to 2019, reaching an all-time high of $23,80 \%$ in the second quarter of 1972 and a record low of $-2,50 \%$ in the fourth quarter of 2013. There is no credit check when joining stokvels, as members trust one another.

Despite high demand for saving among low-income households, South Africa as a whole has a very low savings rate (Moyagabo, 2015). The lack of a formal saving culture has been perpetuated by the high banking fee structures, inaccessibility to formal savings products and the limited financial literacy of low-income households. 
Stokvels are growing in popularity as a savings vehicle, despite official statistics indicating that South Africa has a very low saving rate (Moyagabo, 2015). In South Africa, there is a growing awareness of the need to facilitate understanding by all individuals and households of finances, its benefits and possible risks, as financial services nowadays are available to everyone (Caplinska and Ohotina, 2019). The problem of financial literacy can be particularly limiting for families that live in communities where there is a low median income, where unemployment is common and where financial capability is low (Baron, 2015). The majority of low-income households do not have time to read and write, and a lack of financial knowledge inhibits them from making financially sound decisions, or anticipating future costs relating to a decision made today. In addition, they cannot use bank automatic teller machines (Brown, 2006).

According to Piprek et al. (2004), limited financial literacy and financial understanding leads to poor financial decisions that are often burdensome and irreversible for the affected low-income households. The financial isolation of lowincome households often results in their lack of financial understanding, which in turn leads them to further distance themselves from banks. In lacking basic financial knowledge, low-income households cannot perform simple calculations and the saving behaviour is dominated by crude rule of thumb (Lusardi, 2012).

The South African festive season starts in December when the schools close. Accordingly, low-income households save with stokvels during the year and share investments to buy groceries in bulk, to travel to rural areas, to buy school uniforms, and to pay school fees, furniture as well as for celebrations.

\section{Research Methodology}

\subsection{Sampling Strategy}

This study followed a survey design using a quantitative research approach. Bryman and Bell (2007) define sampling as the selection of a fragment of the population for the research process. A multi-stage sampling strategy was applied in this study and respondents were randomly selected. In the first stage, Gauteng, one of South Africa's nine provinces, was selected because of its proximity to the researcher thus reducing the cost of travel. In the second stage, respondents were drawn from the cities of Pretoria and Johannesburg and, in the third stage, primary research was conducted by distributing self-administered research questionnaires to a sample of 600 stokvel members of which 386 made the final sample. Table 1 below shows the gender distribution of the respondents.

This study adhered to all the principles of the University of South Africa (UNISA) Research Ethics, as well as the main ethical considerations as guided by Babbie (2007). In order to comply with ethical considerations, the researcher applied for and obtained ethical clearance from the University of South Africa (UNISA) prior to 
carrying out the survey. In addition, before completing the questionnaires, respondents were provided with a consent form to sign indicating their voluntary consent to participate in the study (Creswell, 2003). The researcher ensured that the study posed no harm to the respondents (Flick, 2006), who were not compelled to answer the questionnaire. Consistent with Cooper and Schindler (2011), all respondent information was kept confidential.

Table 1. Characteristics of respondents

Source: Own study.

\begin{tabular}{|l|l|}
\hline Total number of stokvels members & $\mathbf{3 8 6}$ \\
\hline Male & $45,1 \%$ \\
Female & $52,3 \%$ \\
\hline
\end{tabular}

\section{Discussion and Interpretation of the Results}

Figure 1 below summarises the demographic information pertaining to the respondents, specifically the respondents' level of education.

Figure 1. Frequency of respondents regarding education

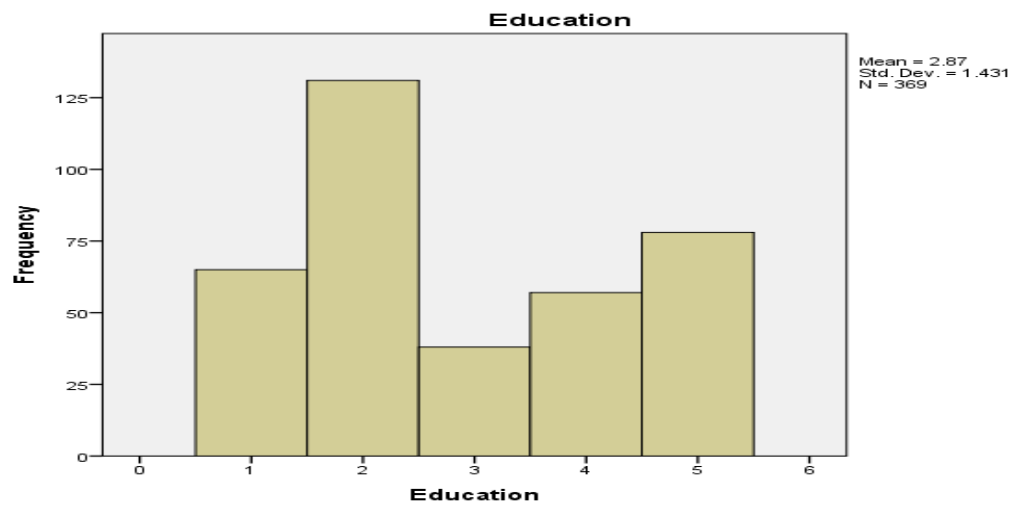

Source: Own study.

The results showed that most of the respondents had a matric, indicated by $33,9 \%$ of the total sample, followed by respondents who were degree holders at $20,2 \%$ of the total sample, while those with no schooling comprised $16,8 \%$ of the total sample, $14,8 \%$ were diploma holders and $9.8 \%$ had a national certificate. The literature states that all South Africans have a right to basic education and the Bill of Rights obliges the government to make education progressively available and accessible through reasonable measures.

According to Berg and Lune (2012), education refers "to the delivery of knowledge, skills and information from teachers to students. Education results in the empowerment of people and enables them to think clearly and act effectively to achieve self-selected goals and aspirations". 
Table 2 indicates the mean and standard deviation of the dependent and independent variables to signify the magnitude to which the sampled respondents strongly agreed with the items in the questionnaire.

Table 2. Descriptive statistics, factors that influence members to participate in stokvels

\begin{tabular}{|l|l|l|l|l|l|}
\hline & $\mathrm{N}$ & Minimum & Maximum & Mean & Std. Dev. \\
\hline $\begin{array}{l}\text { Interest on investment is very } \\
\text { low in banks }\end{array}$ & 94 & 1 & 5 & 4,18 &, 994 \\
\hline $\begin{array}{l}\text { Unlike in a bank, terminating } \\
\text { an investment before } \\
\text { maturity is negotiable }\end{array}$ & 97 & 1 & 5 & 4,10 &, 860 \\
\hline $\begin{array}{l}\text { Investing in a pyramid scheme } \\
\text { generates lots of income }\end{array}$ & 89 & 2 & 5 & 4,07 &, 837 \\
\hline $\begin{array}{l}\text { Investment in pyramid } \\
\text { schemes can be terminated at } \\
\text { any time }\end{array}$ & 86 & 1 & 5 & 4,34 & 1,001 \\
\hline $\begin{array}{l}\text { High festive season cash } \\
\text { requirements }\end{array}$ & 157 & 1 & 44 & 4,62 & 3,342 \\
\hline Valid N (listwise) & 36 & & & & \\
\hline
\end{tabular}

Source: Own study.

\subsection{High Cash Requirements During the Festive Season}

The mean results of the variables show how the respondents assessed each statement. The highest mean was "I invest in a stokvel to provide for high festive season cash requirements" with a numerical value of 4,62. Low-income households save with stokvels and share their savings in December. Members of such households also visit rural areas in December, hence, the majority of the stokvel respondents agreed that, "around the 1930s there was an influx of rural-urban migrants, particularly women, as they arrived in the cities and towns to join their husbands who were working on the mines". In December, groceries are purchased in bulk and distributed equally among members to coincide with year-end festivities (Weavind, 2013).

\subsection{Lower Risk of Failure than Pyramid Schemes}

The second highest mean was "I invest with stokvels because investment in pyramid schemes can be terminated at any time" with a numerical value of 4,34. The literature states that pyramid schemes use money collected from new recruits to pay off early investors until eventually the pyramid collapses. Grobler (2015) noted that poor financial literacy leads to low-income households not taking saving seriously. 


\subsection{Interest rates}

The third highest mean was "I invest with stokvels because interest on investment is very low in banks" with a numerical value of 4,18. Oji (2015) noted that households with low and middle income save their money in stokvels which results in a loss of interest income that would be generated if money were deposited in an account at a formal financial institution.

\subsection{Negotiable Termination of Investment}

The fourth highest mean was "I invest with stokvels because, unlike in a bank, terminating an investment before maturing is negotiable" with a numerical value of 4,0 . Investment in participating stokvels plays an important role in reducing poverty and inequality in Gauteng province. It enables low-income households to save and they can terminate an investment before maturity by negotiating with stokvel members.

\subsection{High Income Earned}

The lowest mean was "I invest with stokvels because investing in pyramid scheme generates lots of income, share cash savings in December" with a numerical value of 4,07. Lack of financial literature, low-income households want to get rich quickly by joining pyramid schemes stokvel, pooling their contributions and investing the money to get higher long-term returns.

The correlation matrix indicates the results of the Pearson product-moment correlation of the continuous variable. As shown in Table 3 , the $r$ value correlation ranges from 0,267 to 0,958 . This indicates a reasonable relationship between constructs, as the $r$ value can range from -1 to 1 . If the value of $r$ is close to 1 there is a stronger relationship between constructs. P-values smaller than 0,05 indicate a significant correlation between constructs.

Table 3. Correlations, Factors and Stokvel Performance

\begin{tabular}{|c|c|c|c|c|c|c|}
\hline & & $\begin{array}{l}\text { Interest on } \\
\text { investment } \\
\text { is very low } \\
\text { in banks }\end{array}$ & $\begin{array}{l}\text { Unlike in a } \\
\text { bank, } \\
\text { terminating } \\
\text { an } \\
\text { investment } \\
\text { before } \\
\text { maturity is } \\
\text { negotiable }\end{array}$ & $\begin{array}{l}\text { Investing } \\
\text { in } \\
\text { pyramid } \\
\text { scheme } \\
\text { generates } \\
\text { lots of } \\
\text { income }\end{array}$ & $\begin{array}{l}\text { Investment } \\
\text { in pyramid } \\
\text { schemes } \\
\text { can be } \\
\text { terminated } \\
\text { at any time }\end{array}$ & $\begin{array}{l}\text { Invest for } \\
\text { high festive } \\
\text { season cash } \\
\text { requirement }\end{array}$ \\
\hline \multirow{3}{*}{$\begin{array}{l}\text { Interest on } \\
\text { investment is } \\
\text { very low in } \\
\text { banks }\end{array}$} & $\begin{array}{l}\text { Pearson } \\
\text { correlation }\end{array}$ & 1 & $.737^{* * *}$ & $.675^{* *}$ & $.713^{* *}$ & .267 \\
\hline & $\begin{array}{ll}\begin{array}{l}\text { Sig. } \\
\text { tailed })\end{array} & (2- \\
\end{array}$ & & .000 & .000 & .000 & .091 \\
\hline & $\mathrm{N}$ & 94 & 37 & 37 & 38 & 41 \\
\hline $\begin{array}{l}\text { Unlike in a } \\
\text { bank, }\end{array}$ & $\begin{array}{l}\text { Pearson } \\
\text { correlation }\end{array}$ & $.737^{* *}$ & 1 & $.865^{* * *}$ & $.958^{* *}$ & .299 \\
\hline
\end{tabular}




\begin{tabular}{|c|c|c|c|c|c|c|}
\hline \multirow{2}{*}{$\begin{array}{l}\text { terminating } \\
\text { an } \\
\text { investment } \\
\text { before } \\
\text { maturity is } \\
\text { negotiable }\end{array}$} & $\begin{array}{l}\text { Sig. } \\
\text { tailed })\end{array}$ & .000 & & .000 & .000 & .076 \\
\hline & $\mathrm{N}$ & 37 & 97 & 36 & 36 & 36 \\
\hline \multirow{3}{*}{$\begin{array}{l}\text { Investing in } \\
\text { pyramid } \\
\text { schemes } \\
\text { generates lots } \\
\text { of income }\end{array}$} & $\begin{array}{l}\text { Pearson } \\
\text { correlation }\end{array}$ & $.675^{*}$ & $.865^{* *}$ & 1 & $.887^{* *}$ & $.479^{* *}$ \\
\hline & $\begin{array}{ll}\begin{array}{l}\text { Sig. } \\
\text { tailed })\end{array} & (2- \\
\end{array}$ & .000 & .000 & & .000 & .002 \\
\hline & $\mathrm{N}$ & 37 & 36 & 89 & 39 & 41 \\
\hline \multirow{3}{*}{$\begin{array}{l}\text { An } \\
\text { investment in } \\
\text { a pyramid } \\
\text { scheme can } \\
\text { be terminated } \\
\text { at any time }\end{array}$} & $\begin{array}{l}\text { Pearson } \\
\text { correlation }\end{array}$ & $.713^{\text {** }}$ & $.958^{* * *}$ & $.887^{* *}$ & 1 & $.328^{*}$ \\
\hline & $\begin{array}{ll}\begin{array}{l}\text { Sig. } \\
\text { tailed })\end{array} & (2- \\
\end{array}$ & .000 & .000 & .000 & & .039 \\
\hline & $\mathrm{N}$ & 38 & 36 & 39 & 86 & 40 \\
\hline \multirow{3}{*}{$\begin{array}{l}\text { To provide } \\
\text { for high } \\
\text { festive } \\
\text { season cash } \\
\text { requirements }\end{array}$} & $\begin{array}{l}\text { Pearson } \\
\text { correlation }\end{array}$ & .267 & .299 & $.479^{* *}$ & $.328^{*}$ & 1 \\
\hline & $\begin{array}{ll}\text { Sig. } & (2- \\
\text { tailed })\end{array}$ & .091 & .076 & .002 & .039 & \\
\hline & $\mathrm{N}$ & 41 & 36 & 41 & 40 & 157 \\
\hline
\end{tabular}

Source: Own study.

\section{Conclusions and Recommendations}

The literature to date has shown that stokvels low-income households are generally financially illiterate. There are important differences that affect financial literacy. One of these is gender, the findings of this research clearly indicate that stokvel participants tend to be mainly women at $52,0 \%$. This is supported by Buijs (2002) and Ngcobo and Chisasa (2018) who found that most women participated in stokvels because they were poor, uneducated and unemployed. In line with this argument, people who are employed but earn a lower income tend to supplement their income by belonging to stokvels (Mboweni, 1990).

In terms of financial literacy, 33,9\% of the total sample indicated that their highest qualification was matric. Lack of financial knowledge, in need of financial literature education and the best ways to improve savings with financial institutions. The Financial Literacy and Education Commission (FLEC, 2011) states that it is "important that all individuals and families, including those of diverse and underserved populations, [be] aware of and have access to reliable, clear, timely, relevant and effective financial information and educational resources".

According to Baron (2015), the problem with financial literacy can be particularly limiting for families who live in communities where incomes are low or median, unemployment is common and financial capability is low. For low-income households, lack of basic financial knowledge and skills in addition to a meagre subsistence level income prohibits them from amassing the savings to even consider investment options. 
This survey developed an indicator of factors related to saving that influence members to participate in stokvels. In this survey, low-income households invest in stokvels to provide for high festive season cash requirements with the highest mean $(4,62)$ and invest in pyramid scheme to generate lots of income with the lowest mean $(4,07)$.

The results of the study can be used to guide policymakers on where to place more emphasis in terms of financial literacy regarding savings for South African lowincome households.

\section{References:}

African Response. 2012. Stokvels - A hidden economy: unpacking the potential of South African traditional saving schemes. http://www.africanresponse.co.za.

Babbie, E. 2007. The practice of social research. 11th edition. Belmont, CA: Wadsworth.

Baron, L.M. 2015. Financial literacy with family opportunity and hope. Journal of Urban Mathematics and Education, 8(1), 83-118. http://education.gsu.edu/JUME.

Berg, B.C., Lune, H. 2012. Qualitative Research Methods for the Social Sciences. $8^{\text {th }}$ edition, Boston, Pearson.

Brown, R., Ivkovic, Z., Smith, P.B., Weisbenner, S. 2006. Neighbors matter: Causal community effects and stock market participation. University of Illinois at UrbaanaChampaign and NBER.

Bryman, A., Bell, E. 2007. Research designs. Business Research Methods. New York. Oxford University Press, 44-73.

Buijs, G. 2002. Rotating credit associations: their formation and use by povertystrickenwomen in Rhini, Grahamstown, Eastern Cape. University of Zululand, 32(1), 27-42.

Caplinska, A., Ohotina, A. 2019. Analysis of Financial Literacy Tendency with Young People. Entrepreneurship and Sustainability Issues, 6(4), 1736-1749. https://doi/org/10.9770/jesi.2019.6.4(13).

Cole, S., Sampson, T., Zia, B. 2011. Prices or knowledge: What drives demand for financial services in emerging markets? Journal of Finance, 666, 1933-1967. https://doi/org/10.1111/j.1540-6261.2911.01696.

Cooper, D., Schindler, P. 2011. Business research methods. 11 th edition, Boston, MA., McGraw-Hill Higher Education.

Creswell, J.W. 2014. Research design, qualitative, quantitative and mixed methods approaches. Sage.

Engelbrecht, L. 2009. Indebtedness of financially vulnerable households: What do social workerd do? Social Work/Maatskaplike Werk, 45(2), 154-170. http://dx.doi.org/10.15270/45-2-212.

Financial Literacy and Education Commission (FLEC). 2011. Promoting financial success in the United States. National Strategy for Financial Literacy. http://www.mymoney.gov.

FinMark Trust. 2007. Access to savings products in the low-income market. Johannesburg: South Africa Savings Institute.

FinMark Trust. 2008. Banking Comes to the People; SA needs more financial education; A Picture of the Financial Services Industry 2008. Press Release.

Flick, U. 2006. An introduction to qualitative research. Qualitative Research in Psychology, । 
4, 259-260. London: Sage Publications.

Gale, W.G., Levine, R. 2010. Financial Literacy: What Works? How Could It Be More Effective? Report, October 1.

Grobler, R. 2015. Snapshot of SA's savings culture. Investec, Specialist Bank, June.

Jappelli, T., Padula, M. 2011. Investment in Financial Literacy and Savings Decisions. Journal of Banking and Finance, 37(8), 1-42. https://doi.org/10.1016/j.jbankfin.2013.03.019.

Lusardi, A., Mitchell, O.S. 2007. Baby boomer retirement security. The roles of planning, financial literacy, and housing wealth. Journal of Monetary Economics, 54(1), 205224.

Lusardi, A. 2008. Household saving behaviour: the role of financial literacy, information, and financial education programs. Dartmouth College and NBER.

Lusardi, A., Mitchell, O.S. 2007. Financial Literacy and Retirement Preparedness: Evidence and Implications for Financial Education. Business Economics, 1(1), 35-44.

Lusardi, A. 2012. Numeracy, financial literacy, and financial decision-making. Numeracy, 5(1), 1-14. https://doi.org/10.5038/1936-4660.5.1.2.

Lusardi. A., Michell, O.S. 2014. The economic importance of financial literacy. Journal of Economic Literature, 52(1), 5-44. https://doi.org/10.1257/jel.52.2.5

Mboweni, T. 1990. Stokvels in South Africa: Informal Savings Schemes by Black for the Black Community. Johannesburg: Amagi Books.

Moyagabo, M. 2015. Stokvels: The cash alternative. Financial Mail, July 30.

Ngcobo, L., Chisasa, J. 2018. Success factors and gender participation of stokvels in South Africa. Acta Universitatis Danubius (Oeconomica), 14(5), 217-228. ISSN: 20650175 .

Oji, C.K. 2015. Promoting financial inclusion for inclusive growth in Africa. Occasional Paper 210. Economic diplomacy Programme. February. SAIIA https://www.saiia.org.za/occasional-papers/promoting-financial-inclusion-forinclusive-growth-in-africa/.

Piprek, G., Dlamini, P.m Coetzee, G. 2004. FinMark Trust Financial literacy scoping study \& strategy project. On behalf of ECIAfrica Consulting (Pty) Ltd.

South African Government. 2015. Premier David Makhura: Stokvel and Burial Society Indaba, 18 September.

South Africa Banking System. 2019. South Africa - Banking Systems / export. Gov. https://www.export.gov.article.id=South-Africa-banking-systems.

Weavind, T. 2013. Safety in numbers still savings model of choice. Business Times 14 July. South Africa. 